Article

\title{
Design, Synthesis and DNA Interaction Study of New Potential DNA Bis-Intercalators Based on Glucuronic Acid
}

\author{
Jiuyang Zhao ${ }^{1, \dagger}$, Wei Li ${ }^{1,2, \dagger}$, Rui Ma ${ }^{1, \dagger}$, Shaopeng Chen ${ }^{1}$, Sumei Ren ${ }^{1}$ and Tao Jiang ${ }^{1, *}$
}

1 Key Laboratory of Marine Drugs, The Ministry of Education of China, School of Pharmacy, Ocean University of China, Qingdao 266003, China; E-Mails: flyawayzhao@163.com (J.Z.); lwlw1919@163.com (W.L.); xrzhsh_2006@126.com (R.M.); chenshaopeng2006@163.com (S.C.); rensumei@ouc.edu.cn (S.R.)

2 School of Pharmacy, Jining Medical University, Rizhao 276826, China

$\dagger$ These authors contributed equally to this study.

* Author to whom correspondence should be addressed; E-Mail: jiangtao@ouc.edu.cn; Tel.: +86-532-8203-2712; Fax: +86-532-8203-3054.

Received: 16 April 2013; in revised form: 30 June 2013 / Accepted: 7 July 2013 /

Published: 15 August 2013

\begin{abstract}
A series of novel potential DNA bis-intercalators were designed and synthesized, in which two glucuronic acids were linked by ethylenediamine, and the glucuronic acid was coupled with various chromophores, including quinoline, acridine, indole and purine, at the $\mathrm{C}-1$ position. The preliminary binding properties of these compounds to calf thymus DNA (CT-DNA) have been investigated by UV-absorption and fluorescence spectroscopy. The results indicated that all the target compounds can interact with CT-DNA, and the acridine derivative, $\mathbf{3 b}$, showed the highest key selection vector (KSV) value, which suggested that compound $\mathbf{3 b}$ binds most strongly to CT-DNA.
\end{abstract}

Keywords: glycuronic acid; DNA bis-intercaltor; synthesis and design

\section{Introduction}

Numerous biological experiments have suggested that DNA is one of the primary cellular targets for many anticancer agents. Particularly, in cancer cells, DNA can be preferentially damaged, due to the interactions with anticancer agents, therefore inhibition/blockage of cell division causes cell 
death [1-5]. The DNA interacting molecules are usually bound to DNA non-covalently by three modes: intercalation, groove binding and static electronic interactions. Static electronic interactions refers to molecules that bind with the negatively charged DNA double helix externally through a non-specific interaction. In groove binding, the targeting molecules interact with DNA in the base edges of the major groove or minor groove, which had been discussed by many groups [6-10]. The intercalation is another DNA binding mode that is closely related to the antitumor ability of many anticancer agents [11].

Intercalators are a group of compounds that interact with the DNA double helix in a reversible manner. Some of them are valuable drugs currently used for the treatment of ovarian and breast cancers, as well as acute leukemia, while many others are in different phases of clinical trials. Intercalating agents share some common structural features, such as the presence of planar polyaromatic systems that are inserted between DNA base-pairs with a marked preference for 5'-pyrimidine-purine-3' sequence. In addition, the chromophores are linked to basic moieties that might also play an important role in the affinity and selectivity shown for compounds [12-15].

Bis-intercalators have two potential intercalating ring systems connected by linkers that can vary in both length and rigidity. In the 1990s, Priebe and co-workers developed the bis-intercalators of daunomycin, which had expanded research ideas [16]. In recent years, the synthesis of bis-intercalators has drawn considerable attention, because, in comparison with mono-intercalators, higher DNA-binding constants, slower dissociation rates and substantial sequence selectivity can be expected by incorporating two or more intercalating units into a polyfunctional ligand [17]. In addition, the interactions with the groove or phosphate groups by the linker may provide enhancement for binding affinity or selectivity [18].

A number of sugar-intercalator conjugates have been studied before for different nucleic acid binding [19-24], and monosaccharides have been introduced as biologically relevant scaffolds. The advantage of using saccharides is to acquire the high density of functional groups. Meanwhile, they are available as single enantiomers and contain multiple sites for attachment of recognition groups [25,26]. In this work, we report the design and synthesis of four potential DNA bis-intercalators based on glucuronic acid (Figure 1). Glucuronic acids, which have a 6- $\mathrm{COOH}$ rather than a $6-\mathrm{CH}_{2} \mathrm{OH}$, are in glycosides converted to amides via coupling with an amine. The intercalation binding force comes from the $\pi-\pi$ interactions and hydrophobic interactions between the aromatic ring of the intercalator and the DNA base, so we chose the planar aromatic molecules, quinoline, acridine, indole and purine, as chromophores to incorporate into these bis-intercalators. The interactions of these bis-intercalators with calf thymus DNA (CT-DNA) were studied.

Figure 1. DNA bis-intercalators 3a-3d.
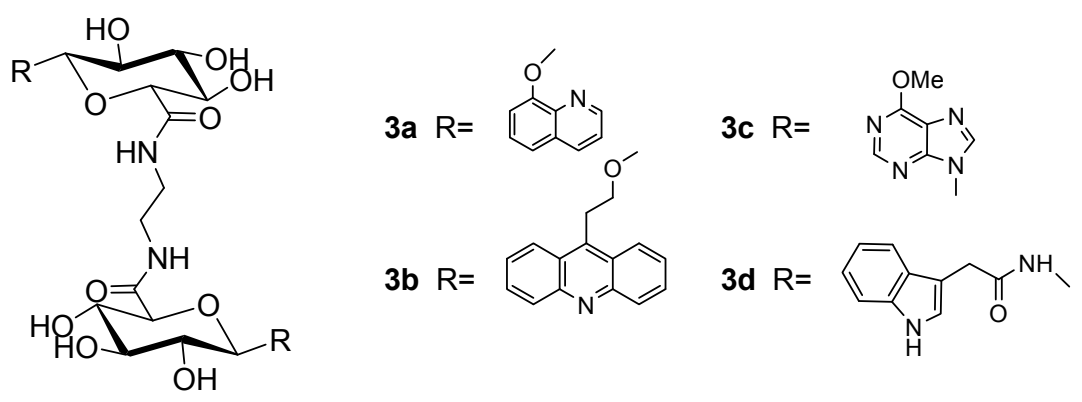


\section{Results and Discussion}

\subsection{Synthesis}

The starting material, glucurono-3,6-lactone, was converted into methyl tetra acetyl glucopyranuronate 2 by methyl esterification and acetylation, according to the literature method [27]. The glycosylating agents, such as glucuronosyl bromide $\mathbf{3}$, glucuronosyl azide $\mathbf{4}$ and glucuronosylamine $\mathbf{5}$, were prepared by bromization, azide substitution and hydrogenation in good yield based on methods described in the literature [28-30].

Then, the acetyl protected glucuronosyl donor was coupled with the derivatives of quinoline, acridine, purine and indole, respectively, to give the methyl (aryl glucuronosyl)-uronates. Compound 1a was synthesized (57.6\% yield) via the reaction of 3 with 8-hydroxylquinoline (3 Eq.) using $\operatorname{Ag}_{2} \mathrm{O}$ (5 Eq.) as catalyst. Trimethylsilyl trifluoromethanesulfonate (TMSOTf) promoted coupling of 2, with 9- $\beta$-hydroxylethyl acridine giving $\mathbf{1 b}(24.2 \%$ yield). The reaction of $\mathbf{3}$ with Cloromercuri-6-chloropurine catalyzed by $\mathrm{CdCO}_{3}$ gave 1c (35\% yield) [31]. Compound 1d was prepared from the azide $\mathbf{4}$ through reduction to the amine $\mathbf{5}$, and subsequent coupling was performed with 2-(indol-3-yl)acetic acid promoted by 1-ethyl-3-(3-dimethylaminopropyl)carbodiimide (EDCI) [30]. (Scheme 1).

Scheme 1. Reagents and conditions: (i) $\mathrm{Ag}_{2} \mathrm{O}, \mathrm{CH}_{2} \mathrm{Cl}_{2}, 58 \%$; (ii) Trimethylsilyl trifluoromethanesulfonate (TMSOTf), $\mathrm{CH}_{2} \mathrm{Cl}_{2}, 35 \%$; (iii) $\mathrm{CdCO}_{3}$, Celite, toluene, reflux; (iv) 1-ethyl-3-(3-dimethylaminopropyl)carbodiimide (EDCI), tetrahydrofuran (THF), 30\%.

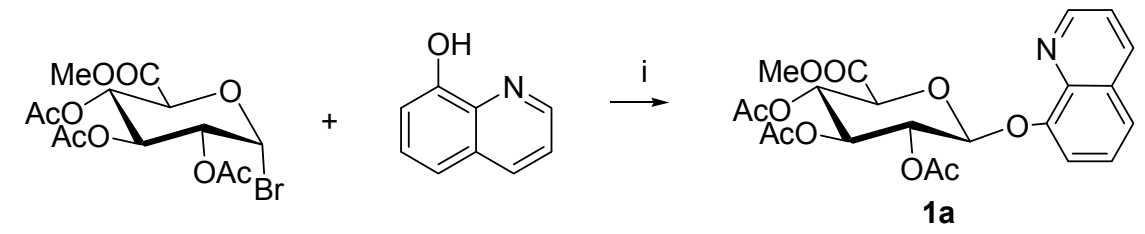

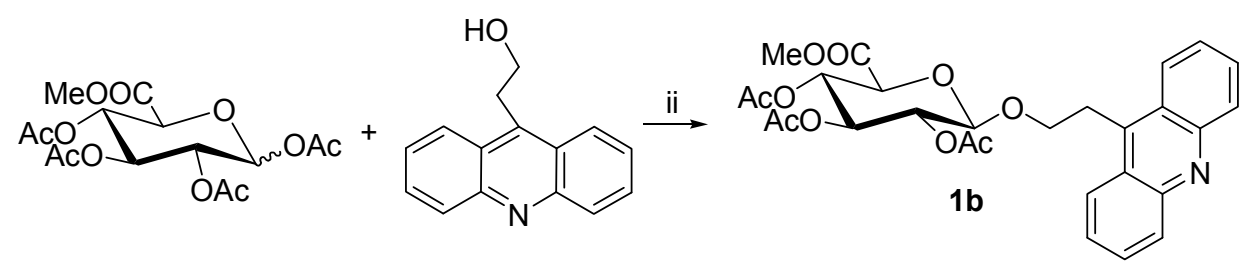

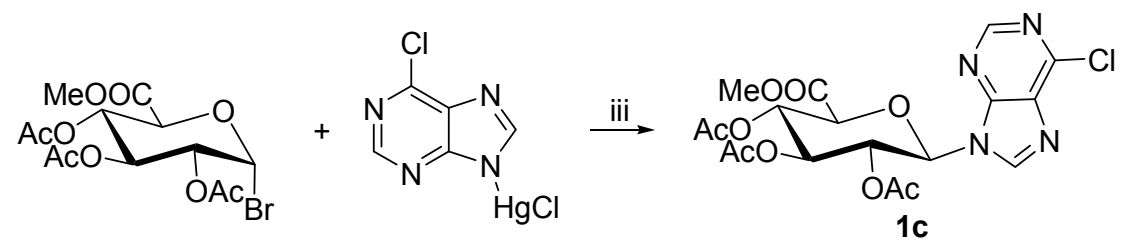

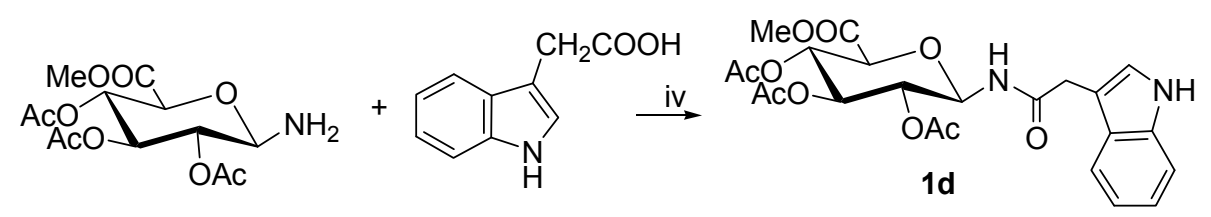


Deacetylation by $\mathrm{MeONa} / \mathrm{MeOH}$ and treatment of these (aryl glucuronosyl)-uronates (2a-2d) with 0.5 eq. ethylenediamine in methanol under reflux afforded the target bis-intercalators (compound 3a-3d, yield 15\% 25\% Scheme 2).

Scheme 2. Reagents and conditions: (i) $\mathrm{MeONa}, \mathrm{MeOH}$; (ii) $\mathrm{H}_{2} \mathrm{~N}\left(\mathrm{CH}_{2}\right)_{2} \mathrm{NH}_{2}, \mathrm{MeOH}$, reflux, yield 15\% 25\%.

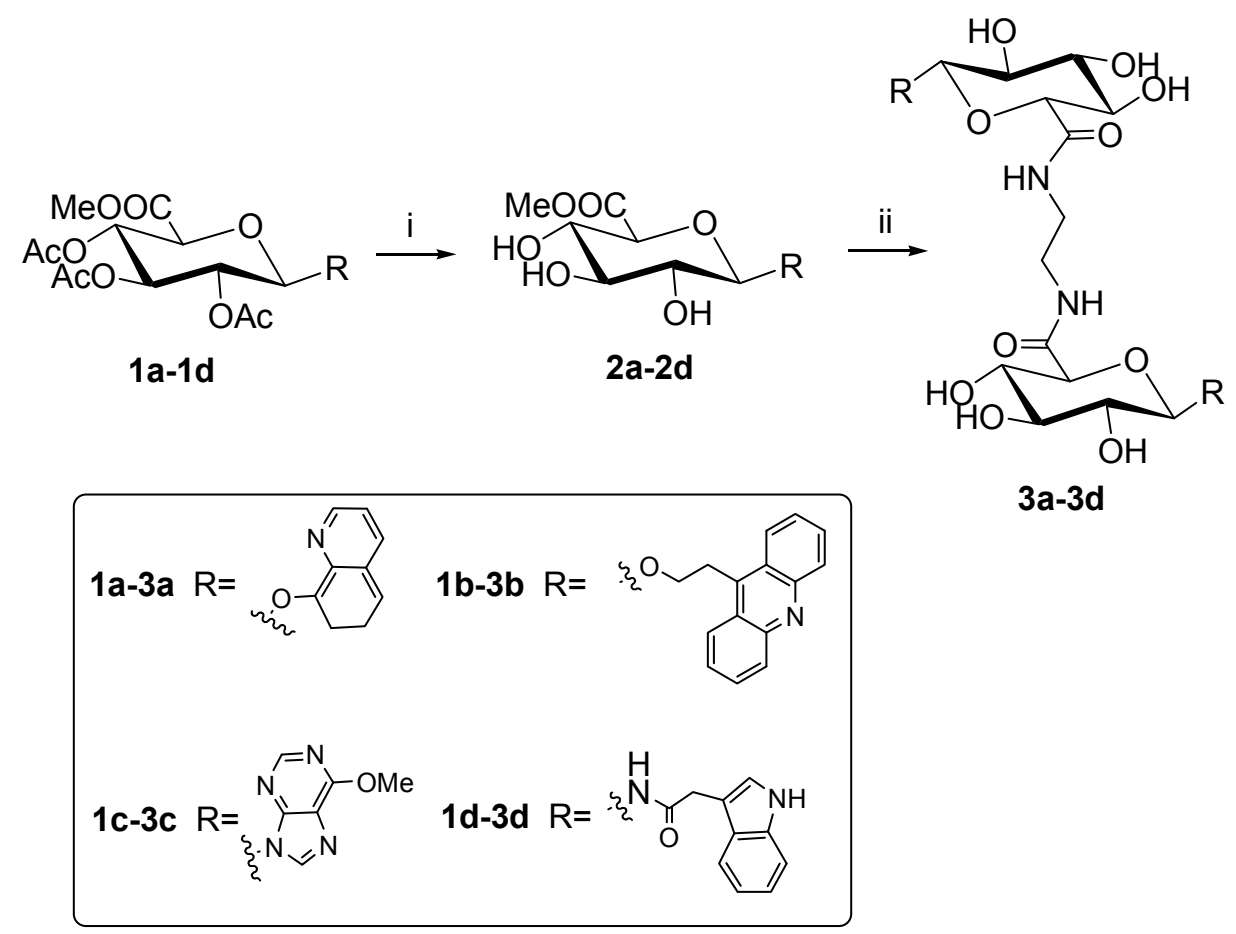

\subsection{DNA Binding Properties}

To study how efficiently the synthesized compounds interact with CT-DNA, we investigated their DNA binding primary properties by UV absorption and fluorescence emission spectra.

\subsubsection{UV Absorption}

The measurement of UV absorption of compounds was conducted in the phosphate buffer by using a fixed compound concentration $\left(2 \times 10^{-5} \mathrm{M}\right)$ to which increments of the CT-DNA stock solution was added. The solutions were allowed to incubate for $5 \mathrm{~min}$ before the absorption spectra were recorded. The UV absorption band of compound 3c and 3d was similar to that of the DNA duplex, around the wavelength of $260 \mathrm{~nm}$; only UV absorption spectra of compound 3a and $\mathbf{3 b}$ were measured.

The change in compound $\mathbf{3 a}$ and $\mathbf{3 b}$ UV absorption spectra with increasing concentration of CT-DNA is shown in Figure 2. Specifically, both compounds showed hypochromicity upon increasing DNA concentration, indicating that both compounds interacted with the DNA helix. However, a weak hypochromic effect is indeed observed, and no red shift is apparent. So, these changes were not significant enough to accurately determine the DNA-binding constants. 
Figure 2. Absorption spectra of compound 3a, 3b $\left(2 \times 10^{-5} \mathrm{~mol} / \mathrm{L}\right)$ in the presence of calf thymus DNA (CT-DNA) in phosphate buffer containing. [DNA]: (a) 0 ; (b) $2 \times 10^{-5} \mathrm{~mol} / \mathrm{L}$; (c) $4 \times 10^{-5} \mathrm{~mol} / \mathrm{L}$; (d) $6 \times 10^{-5} \mathrm{~mol} / \mathrm{L} ;$ (e) $8 \times 10^{-5} \mathrm{~mol} / \mathrm{L} ;$ (f) $1 \times 10^{-4} \mathrm{~mol} / \mathrm{L}$; (g) $1.2 \times 10^{-4} \mathrm{~mol} / \mathrm{L}$.

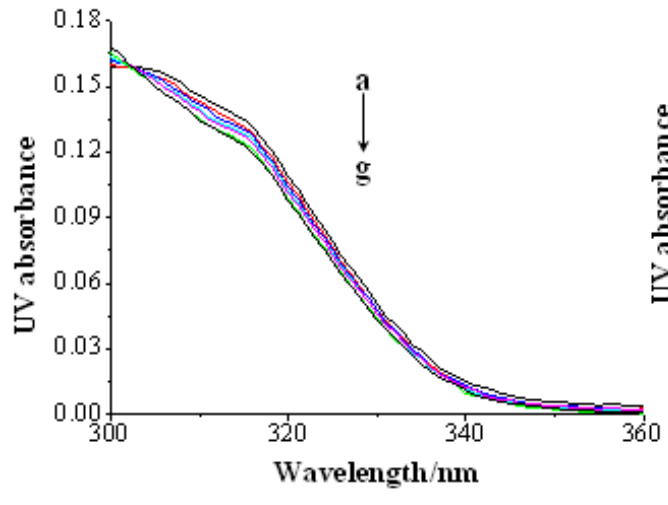

3 a

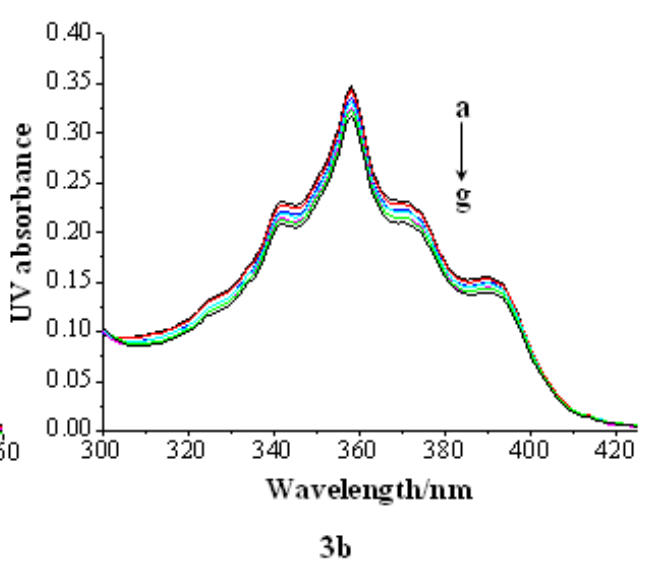

3b

Figure 3. Fluorescence spectra of $\mathbf{3 a}-\mathbf{3 d}\left(2 \times 10^{-5} \mathrm{~mol} / \mathrm{L}\right)$ in the presence of CT-DNA in $\mathrm{pH}=7.0$ phosphate buffer containing. [DNA]: (a) 0 ; (b) $1 \times 10^{-5} \mathrm{~mol} / \mathrm{L} ;$ (c) $2 \times 10^{-5} \mathrm{~mol} / \mathrm{L}$; (d) $3 \times 10^{-5} \mathrm{~mol} / \mathrm{L}$; (e) $4 \times 10^{-5} \mathrm{~mol} / \mathrm{L}$; (f) $5 \times 10^{-5} \mathrm{~mol} / \mathrm{L}$; (g) $6 \times 10^{-5} \mathrm{~mol} / \mathrm{L}$; (h) $7 \times 10^{-5} \mathrm{~mol} / \mathrm{L}$. Arrows show the intensity change upon increasing DNA concentrations. 3a: $\lambda_{\mathrm{ex}}=300 \mathrm{~nm}, \mathbf{3 b}: \lambda_{\mathrm{ex}}=350 \mathrm{~nm}, \mathbf{3 c}: \lambda_{\mathrm{ex}}=290 \mathrm{~nm}, \mathbf{3 d}: \lambda_{\mathrm{ex}}=300 \mathrm{~nm}$.

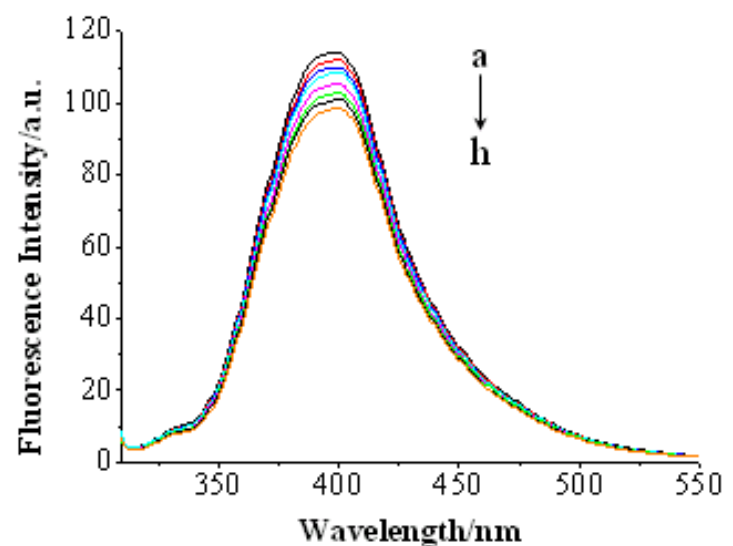

3 a

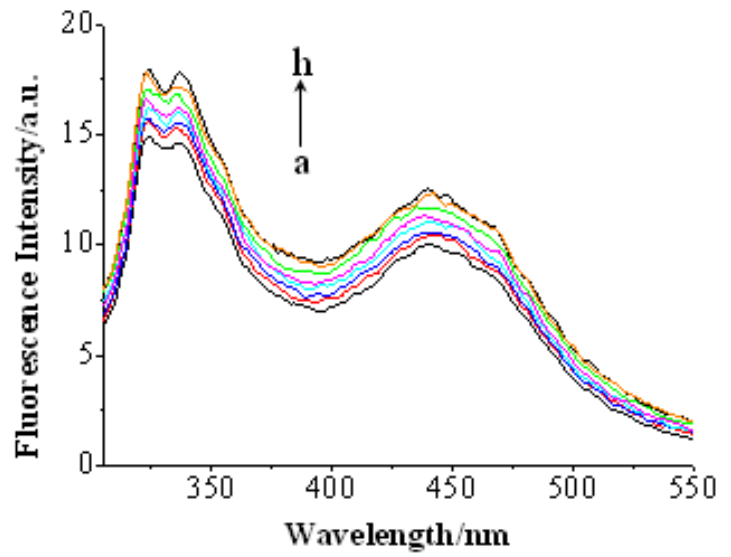

$3 c$

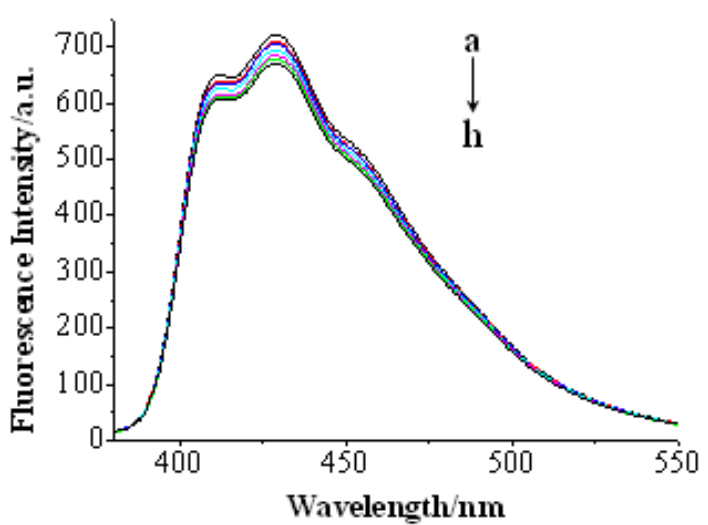

$3 \mathbf{b}$

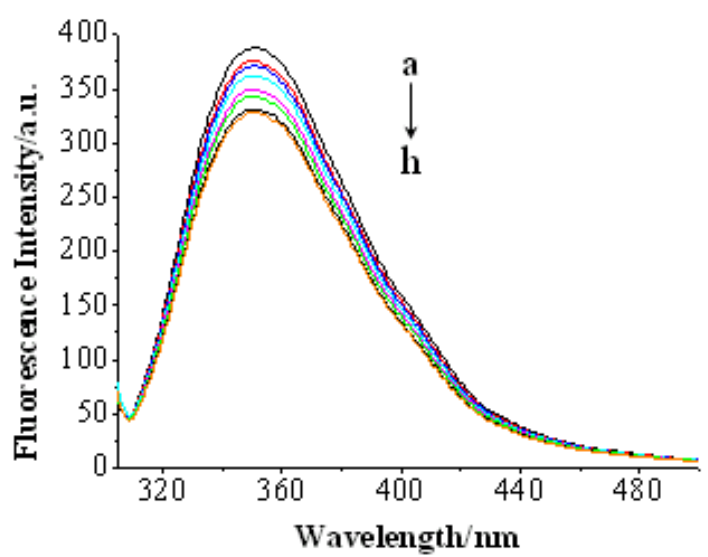

$3 d$ 


\subsubsection{Fluorescence Emission}

The fluorescence titration experiment has been widely used to characterize the compound-DNA interactions, in which the fluorescence emissions of interacting compounds can be quenched, which results in the decrease of fluorescence intensity [32,33]. On the other hand, in some compounds, the compound-DNA interactions can prevent the compound fluorescence emission from being quenched by polar solvent molecules. Consequently, the fluorescence intensity increases [33]. In this study, the interactions between the compounds and CT-DNA were investigated by fluorescence titration. The results are shown in Figure 3. Specifically, the fluorescence intensity of compound 3a, 3b and 3d decreased when titrated by CT-DNA, being in good agreement with the fluorescence behavior of other intercalators reported in the literature [17]. On the contrary, an increase in the fluorescence intensity of compound 3c was observed. The results indicated that all the compounds can interact with CT-DNA, whereas the binding mode may be different.

\subsubsection{EB Competition Assay}

The well-established quenching assay based on the displacement of the intercalating dye, ethidium bromide (EB), from CT-DNA was employed to further investigate the interaction mode between the complexes and CT-DNA. EB is a very useful DNA structural probe, which shows a significant increase in fluorescence intensity when intercalating into the base pair of DNA. However, the enhanced fluorescence can be quenched evidently when there is a second complex that can replace the bound EB or break the secondary structure of DNA [33-35]. It has been reported that the groove DNA binders can also cause the decrease in EB emission intensities. The effects were, however, only moderate [36].

Before we started the fluorescence test of the compounds with DNA, we tried different excitation wavelengths from 280 to $550 \mathrm{~nm}$ and found only one fluoresce for each compound, and each had a fixed wavelength, so we chose the excitation wavelength that is similar with the UV absorbance one. All the compounds do not fluoresce with an excitation at $518 \mathrm{~nm}$.

The EB competition assay results are shown in Figure 4. The fluorescence intensity of DNA-bound $\mathrm{EB}$ at $586 \mathrm{~nm}$ decreased remarkably with the increase of the compound (3a-3d) concentrations. This decrease in fluorescence intensity may be due to the quenching of some EB molecules that were released from DNA into the solution after being replaced by the compounds.

The similar phenomenon that the fluorescence of DNA-bound EB was quenched as a result of the DNA and compound interactions, a characteristic sign of intercalation [37], has also been reported for the chitosan complex [38].

The fluorescence quenching of DNA-bound EB can be well described by the linear Stern-Volmer equation [39] in which the synthesized compounds were the quenchers:

$$
I_{0} / I=1+K S V[Q]
$$

$I_{0}$ and $I$ represent the fluorescence intensities in the absence and presence of quencher, respectively; $K S V$ is a linear Stern-Volmer quenching constant; $Q$ is the concentration of quencher. The KSV values were given by the ratio of the slope to intercept. The KSV values for the tested compounds are listed in Table 1. 
Figure 4. Fluorescence changes that occur when the CT-DNA-ethidium bromide (EB) system is titrated with 3a-3d in phosphate buffer $(\mathrm{pH}=7.0), \lambda_{\mathrm{ex}}=518 \mathrm{~nm}$, $[\mathrm{EB}]=1 \times 10^{-5} \mathrm{~mol} / \mathrm{L}$, [DNA] $=1 \times 10^{-4} \mathrm{~mol} / \mathrm{L}$; [compound]: (a) 0 ; (b) $1 \times 10^{-5} \mathrm{~mol} / \mathrm{L}$; (c) $2 \times 10^{-5} \mathrm{~mol} / \mathrm{L}$; (d) $3 \times 10^{-5} \mathrm{~mol} / \mathrm{L}$; (e) $4 \times 10^{-5} \mathrm{~mol} / \mathrm{L}$; (f) $5 \times 10^{-4} \mathrm{~mol} / \mathrm{L}$; (g) $6 \times 10^{-5} \mathrm{~mol} / \mathrm{L}$. Arrows show the intensity change upon increasing DNA concentrations. Inset: plot of $\mathrm{I}_{0} / \mathrm{I}$ vs. [compound] for the titration of the compound to CT-DNA-EB.

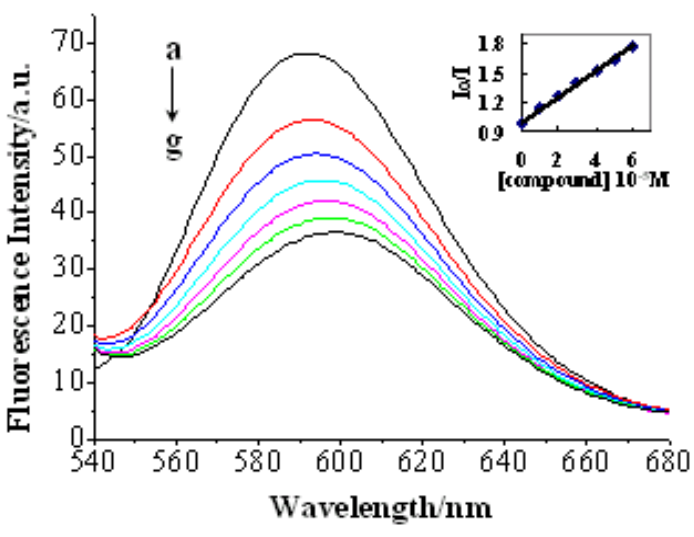

3 a

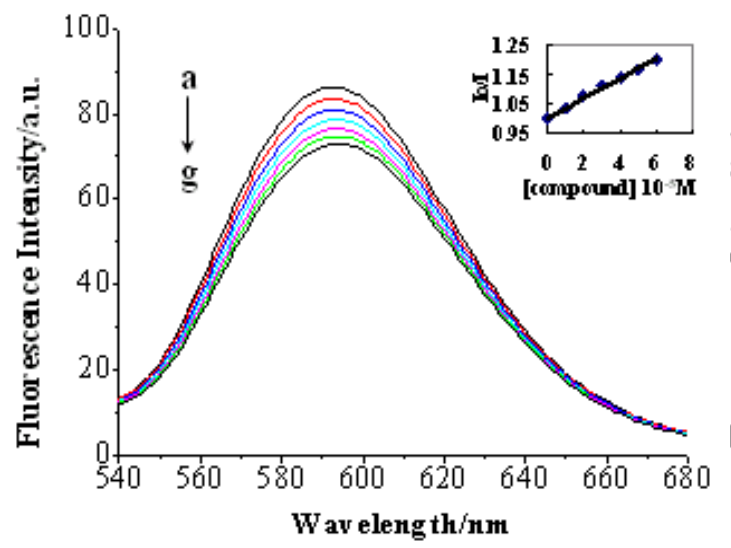

$3 c$

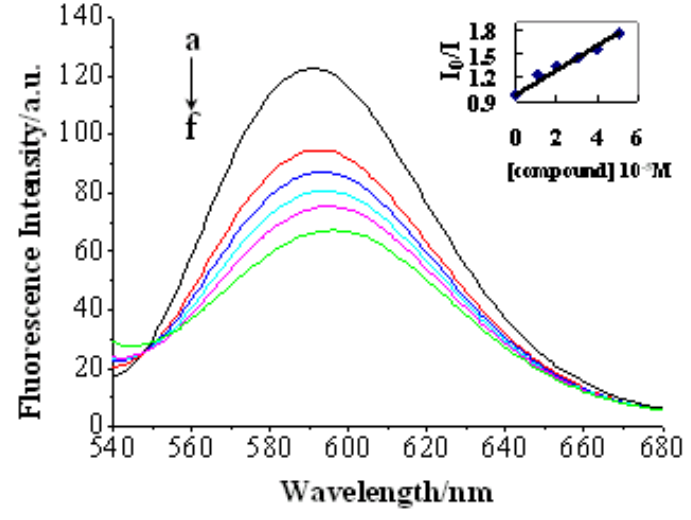

3b

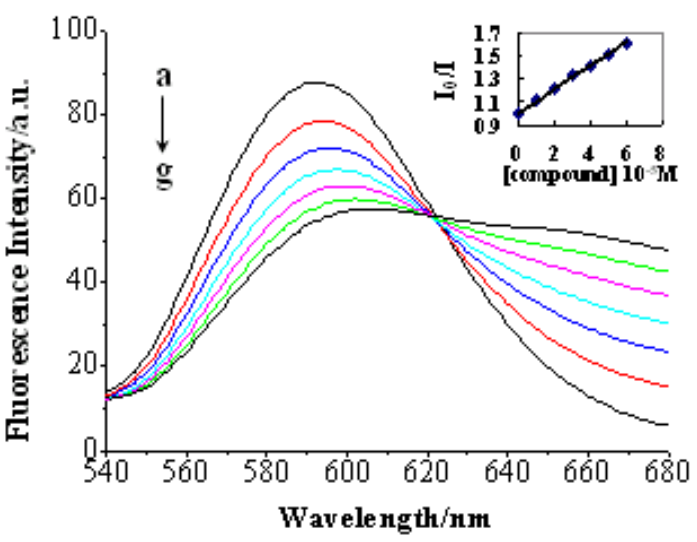

$3 d$

As shown is Table 1, compound $\mathbf{3 b}$ had the highest KSV value, which suggested that compound $\mathbf{3 b}$ bound most strongly to CT-DNA. The classic intercalators, such as acridine derivatives, seemed to be the most efficient. Further investigations are being currently conducted in our laboratory to obtain an efficient dye group (or proper linker) for the bis-intercalators.

Table 1. The key selection vector (KSV) value of compound $\mathbf{3 a}-\mathbf{3 d}$.

\begin{tabular}{ccccc}
\hline Entry & Compound 3a & Compound 3b & Compound 3c & Compound 3d \\
\hline$K S V$ & $1.30 \times 10^{4}$ & $1.54 \times 10^{4}$ & $3.4 \times 10^{3}$ & $1.04 \times 10^{4}$ \\
$R$ (for 5 points) & 0.998 & 0.982 & 0.995 & 0.998 \\
\hline
\end{tabular}




\section{Experimental Section}

\subsection{General Methods}

All reagents and solvents were purchased commercially and purified in a conventional manner. Thin layer chromatography (TLC) was performed on precoated E. Merck Silica Gel 60 F254 plates. Flash column chromatography was performed on silica gel (200-300 mesh, Qingdao, China). ${ }^{1} \mathrm{H}$ NMR and ${ }^{13} \mathrm{C}$ NMR spectra were taken on a Jeol JNM-ECP 600 spectrometer with tetramethylsilane $\left(\mathrm{Me}_{4} \mathrm{Si}\right)$ as the internal standard, and chemical shifts are recorded in d-values. Mass spectra were recorded on a Q-TOF Global mass spectrometer.

\subsection{DNA-Binding Studies}

Calf thymus DNA (CT-DNA) was obtained from Sigma (Sigma, St. Louis, MO, USA). All experiments involving CT-DNA were performed in $10 \mathrm{mM}$ phosphate buffered saline (PBS, $100 \mathrm{mM}$ $\mathrm{NaCl}, \mathrm{pH}=7.0$ ). The per nucleotide DNA concentration was determined by absorption at $260 \mathrm{~nm}$ [40] with the molar absorption coefficient of $6600 \mathrm{M}^{-1} \mathrm{~cm}^{-1}$. A ratio of $260 \mathrm{~nm} / 280 \mathrm{~nm}$ around $1.8-1.9$ indicated high quality of the CT-DNA sample (free of protein contamination) [41]. Stock DNA solutions $\left(c=1.67 \times 10^{-2} \mathrm{M}\right)$ were stored at $4{ }^{\circ} \mathrm{C}$ and for no longer than 4 days before use (1.8 $\mu \mathrm{L}$ solution was added to the cuvette, which makes the concentration of DNA $1 \times 10^{-5} \mathrm{M}$, and the added total volume is $10.8 \mu \mathrm{L}$ when the ratio of compound to DNA is $1: 3$ ).

The UV-visible absorption spectra of DNA binding studies were performed on a Shimadzu UV-2550 spectrophotometer (Shimadzu Co., Kyoto, Japan). The fluorescence spectra were measured with a Fp-750w Fluorometer. The absorption and fluorescence titration samples contained small aliquots of DNA solution and the same concentration of the synthesized compound. All the tested compounds were evaluated in 50\% DMSO, because they were poorly soluble. The fluorescence spectra of the complexes were recorded by using the excitation wavelength of $300 \mathrm{~nm}$ for $\mathbf{3 a}$ and 3d, $350 \mathrm{~nm}$ for $\mathbf{3 b}$ and $290 \mathrm{~nm}$ for 3c. The emission wavelength were as follows: $399 \mathrm{~nm}$ for $\mathbf{3 a}, 429 \mathrm{~nm}$ for $\mathbf{3 b}, 324 \mathrm{~nm}$ for $\mathbf{3 c}$ and $350 \mathrm{~nm}$ for 3d. Before measurements, the mixture was mixed well and incubated at room temperature for $5 \mathrm{~min}$.

In the ethidium bromide (EB) fluorescence displacement experiment, $5 \mu \mathrm{L}$ of the EB Tris solution $(1 \mathrm{mM})$ was added to $1 \mathrm{~mL}$ of DNA solution $\left(1 \times 10^{-4} \mathrm{~mol} / \mathrm{L}\right.$, at saturated binding level) [42], followed by a $2 \mathrm{~h}$ incubation in the dark. The DNA/compound complex was then titrated into the EB/DNA mixture. Before measurements, the solution was well mixed and incubated at room temperature for $30 \mathrm{~min}$. Fluorescence spectra of EB bound to DNA were obtained at an excitation wavelength of $518 \mathrm{~nm}$ and an emission wavelength of $586 \mathrm{~nm}$.

\subsection{Synthesis}

8-O-(methyl 2,3,4-tri- $O$-acetyl- $\beta$-D-glucuronosyluronate)quinolin (1a)

To a solution of $2(1.0 \mathrm{~g}, 2.5 \mathrm{mmol})$ and 8-hydroxylquinolin $(1.08 \mathrm{~g}, 7.5 \mathrm{mmol})$ in dry $\mathrm{CH}_{2} \mathrm{Cl}_{2}$, $(25 \mathrm{~mL})$ was added freshly prepared $\mathrm{Ag}_{2} \mathrm{O}(2.9 \mathrm{~g}, 12.5 \mathrm{mmol})$. The resulting solution was allowed to stir $12 \mathrm{~h}$ at room temperature (r.t.) away from light, then diluted with EtOAc $(25 \mathrm{~mL})$ and filtered 
through Celite. The filtrate was washed with aqueous saturated $\mathrm{NaHCO}_{3}$ and water, followed by drying over $\mathrm{MgSO}_{4}$. The resulting solution was further concentrated under reduced pressure and purified by silica gel chromatography (petroleum ether: EtOAc $=3: 2)$ to yield product $\mathbf{1 a}(0.64 \mathrm{~g}$, 57.6\%) (white solid, mp 66-68 $\left.{ }^{\circ} \mathrm{C}\right) .{ }^{1} \mathrm{H} \mathrm{NMR}\left(\mathrm{CDCl}_{3}, 600 \mathrm{MHz}\right): \delta: 8.90(\mathrm{dd}, 1 \mathrm{H}, J=1.4,4.1 \mathrm{~Hz}$, H-2), 8.14 (dd, 1H, J=1.9, 8.2 Hz, H-4), 7.59 (dd, 1H, J=2.8, 6.4 Hz, H-5), 7.46 (m, 2H, H-3, H-6), 7.43 (dd, 1H, $J=4.1,8.3 \mathrm{~Hz}, \mathrm{H}-7), 5.57$ (d, 1H, $\left.J=7.8 \mathrm{~Hz}, \mathrm{H}-1^{\prime}\right), 5.43$ (m, 3H, H-3', H-4',H-5'), 4.16 $\left(\mathrm{dd}, 1 \mathrm{H}, J=2.3,6.8 \mathrm{~Hz}, \mathrm{H}-2^{\prime}\right), 3.7\left(\mathrm{~s}, 3 \mathrm{H}, \mathrm{OCH}_{3}\right), 2.04-2.10$ (3s, each $\left.3 \mathrm{H}, \mathrm{Ac}-\mathrm{H}\right)$; ESI-MS: $m / z$ $[\mathrm{M}+\mathrm{H}]^{+}: 462.9$.

8-O-(methyl $\beta$-D-glucuronosyluronate)quinolin (2a)

A solution of $1 \mathrm{a}(0.6 \mathrm{~g}, 1.3 \mathrm{mmol})$ in methanol $(15 \mathrm{~mL})$ was treated with sodium methoxide $(0.4 \mathrm{~mol} / \mathrm{L}, 0.6 \mathrm{~mL})$ for $6 \mathrm{~h}$ at room temperature. The mixture was acidified to $\mathrm{pH} 6$ by addition of Amberlite IR-120 $\left(\mathrm{H}^{+}\right)$. The resin was removed by filtration, the filtrate was concentrated and a white solid (2a, $0.32 \mathrm{~g}, 73.5 \%$ yield) was obtained. mp 133-135 ${ }^{\circ} \mathrm{C} .{ }^{1} \mathrm{H} \mathrm{NMR}\left(\mathrm{CDCl}_{3}, 600 \mathrm{MHz}\right) \delta: 8.89$ (dd, 1H, $J=1.8,4.1 \mathrm{~Hz}, \mathrm{H}-2), 8.37$ (dd, 1H, $J=1.9,8.3 \mathrm{~Hz}, \mathrm{H}-4), 7.64$ (d, 1H, $J=7.8 \mathrm{~Hz}, \mathrm{H}-5), 7.58$ (dd, 1H, $J=4.1,8.3 \mathrm{~Hz}, \mathrm{H}-3), 7.54$ (dd, $1 \mathrm{H}, J=8.2,7.8 \mathrm{~Hz}, \mathrm{H}-6), 7.40$ (dd, 1H, $J=0.9,7.8 \mathrm{~Hz}, \mathrm{H}-7$ ), $5.38\left(\mathrm{~d}, 1 \mathrm{H}, J=7.8 \mathrm{~Hz}, \mathrm{H}-1^{\prime}\right), 4.12\left(\mathrm{~d}, 1 \mathrm{H}, J=9.7 \mathrm{~Hz}, \mathrm{H}-2^{\prime}\right), 3.65\left(\mathrm{~s}, 3 \mathrm{H}, \mathrm{OCH}_{3}\right), 3.38-3.51$ (m, 3H, H-3', H-4', H-5'); ESI-MS: $m / z$ [M+H] $]^{+}$:336.2.

$N, N$-1,2-di-(1-O-(quinolin-8-yl)- $\beta$-D-glucuronamide)ethane (3a)

Ethylenediamine $(0.03 \mathrm{~g}, 0.5 \mathrm{mmol})$ was added to a solution of $1 \mathbf{a}(0.32 \mathrm{~g}, 0.95 \mathrm{mmol})$ in methanol $(15 \mathrm{~mL})$. The reaction mixture was stirred under reflux for 2 days, then cooled to room temperature, and the precipitate formed was filtered and washed with hot methanol $(10 \mathrm{~mL} \times 3)$. The titled compound, 3a (80 mg, 25.0\% yield), was obtained as a white solid. mp $202-205{ }^{\circ} \mathrm{C} .{ }^{1} \mathrm{H}$ NMR $\left(\mathrm{DMSO}-d_{6}, 600 \mathrm{MHz}\right) \delta: 8.89$ (dd, $\left.1 \mathrm{H}, J=1.4,4.1 \mathrm{~Hz}, \mathrm{H}-2\right), 8.37$ (dd, $\left.1 \mathrm{H}, J=1.9,8.3 \mathrm{~Hz}, \mathrm{H}-4\right), 8.08$ (s, 1H, NH), 7.64 (d, 1H, J=7.3 Hz, H-5), 7.58 (dd, 1H, J=4.1, 8.3 Hz, H-3), 7.54 (t, 1H, J= 7.8, $8.3 \mathrm{~Hz}, \mathrm{H}-6), 7.41$ (d, 1H, $J=7.8 \mathrm{~Hz}, \mathrm{H}-7), 5.23-5.77$ (3d, 3H, 3OH), 5.20 (d, 1H, J= $\left.7.7 \mathrm{~Hz}, \mathrm{H}-1^{\prime}\right)$, 3.81 (d, $\left.1 \mathrm{H}, J=9.6 \mathrm{~Hz}, \mathrm{H}-2^{\prime}\right), 3.48$ (m, 2H, H-4', H-5'), 3.12 (b, 2H, $\mathrm{CH}_{2}$ ); ${ }^{13} \mathrm{C}$ NMR (DMSO- $d_{6}$, $150 \mathrm{MHz}) \delta$ : $168.45(\mathrm{C}=\mathrm{O}), 152.3,149.3,139.7,136.2,129.1,126.8,121.9,121.8,114.1,101.0,76.2$, 75.9, 73.1, 71.2, 38.1; ESI-MS: $m / z[\mathrm{M}+\mathrm{H}]^{+}:$667.2; HRMS(ESI): calcd. for $\mathrm{C}_{32} \mathrm{H}_{35} \mathrm{~N}_{4} \mathrm{O}_{12}{ }^{+} 667.2251$, found 667.2276 .

9-O-(methyl 2,3,4-tri-O-acetyl- $\beta$-D-glucuronosyluronate)ethyl acridine (1b)

To a solution of methyl tetra acetyl- $\beta$-D-glucopyranuronate $(1.7 \mathrm{~g}, 4.5 \mathrm{mmol})$ and 9- $\beta$-hydroxyethyl-acridine $(0.94 \mathrm{~g}, 4.2 \mathrm{mmol})$ in dry $\mathrm{CH}_{2} \mathrm{Cl}_{2}(25 \mathrm{~mL})$ was added dropwise to a solution of TMSOTf $(1.13 \mathrm{~mL}, 6.75 \mathrm{mmol})$ in $\mathrm{CH}_{2} \mathrm{Cl}_{2}(10 \mathrm{~mL})$ on an ice bath. The reaction mixture was allowed to stir on the ice bath for $30 \mathrm{~min}$, and then it was removed and allowed to stir at r.t. overnight. The reaction mixture was diluted with further $\mathrm{CH}_{2} \mathrm{Cl}_{2}(30 \mathrm{~mL})$, then washed with aqueous saturated $\mathrm{NaHCO}_{3}$ and water, dried over $\mathrm{MgSO}_{4}$. After filtration the solvent was removed under reduced pressure to give a mixture of products that was purified by column chromatography (petroleum ether: 
EtOAc $=2: 1)$ to give $0.55 \mathrm{~g}(24.2 \%$ yield $)$ of $\mathbf{1 b}$ as a light yellow solid $\left(\mathrm{mp} 106-110{ }^{\circ} \mathrm{C}\right) .{ }^{1} \mathrm{H}$ NMR $\left(\mathrm{DMSO}-d_{6}, 600 \mathrm{MHz}\right) \delta: 8.39$ (m, 2H, H-4, H-5), 8.14 (m, 2H, H-1, H-8), 7.84 (dd, 2H, J = 7.3, $7.8 \mathrm{~Hz}, \mathrm{H}-3, \mathrm{H}-6), 7.61$ (dd, 2H, $J=7.7,7.4 \mathrm{~Hz}, \mathrm{H}-2, \mathrm{H}-7), 5.23$ (d, 1H, $\left.J=9.6 \mathrm{~Hz}, \mathrm{H}-1^{\prime}\right), 4.92$ (dd, 1H, $\left.J=10.1,9.6 \mathrm{~Hz}, \mathrm{H}-4^{\prime}\right), 4.89$ (t, 1H, $\left.J=7.7 \mathrm{~Hz}, \mathrm{H}-3^{\prime}\right), 4.69$ (dd, 1H, $J=9.6,8.3 \mathrm{~Hz}, \mathrm{H}-2^{\prime}$ ), 4.43 (d, 1H, $\left.J=10.1 \mathrm{~Hz}, \mathrm{H}-5^{\prime}\right), 4.01-3.93$ (m, 4H, $\left.\mathrm{CH}_{2} \mathrm{CH}_{2}\right), 3.64$ (s, 3H, OCH$)_{3}, 1.96$ (s, 3H, Ac-H), 1.90 (s, 3H, Ac-H), 1.58 (s, 3H, Ac-H); ESI-MS: $m / z[\mathrm{M}+\mathrm{H}]^{+}: 540.1$.

9-O-(methyl $\beta$-D-glucuronosyluronate)ethyl acridine (2b)

To a solution of $\mathbf{1 b}(0.54 \mathrm{~g}, 1.0 \mathrm{mmol})$ in methanol $(15 \mathrm{~mL})$ was treated with sodium methoxide $(0.4 \mathrm{~mol} / \mathrm{L}, 0.8 \mathrm{~mL})$ for $12 \mathrm{~h}$ at room temperature. The reaction mixture was acidified to $\mathrm{pH} 6$ by addition of Amberlite IR-120 $\left(\mathrm{H}^{+}\right)$. The resin was removed by filtration, and the filtrate was concentrated, then purified on silica gel column chromatography eluted with EtOAc to give $0.26 \mathrm{~g}$ (63.4\% yield) of $\mathbf{2 b}$ as a light yellow solid (mp 143-145 ${ }^{\circ} \mathrm{C}$ ). ${ }^{1} \mathrm{H}$ NMR (DMSO- $\left.d_{6}, 600 \mathrm{MHz}\right) \delta: 8.44$ (m, 2H, H-4, H-5), 8.15 (m, 2H, H-1, H-8), 7.85 (m, 2H, H-3, H-6), 7.64 (m, 2H, H-2, H-7), 5.34 $(\mathrm{d}, 1 \mathrm{H}, J=5.9 \mathrm{~Hz}), 5.17(\mathrm{~d}, 1 \mathrm{H}, J=5.0 \mathrm{~Hz}), 5.16(\mathrm{~d}, 1 \mathrm{H}, J=5.0 \mathrm{~Hz}), 4.47\left(\mathrm{~d}, 1 \mathrm{H}, J=7.8 \mathrm{~Hz}, \mathrm{H}-1^{\prime}\right)$, 4.04-3.92 (m, 4H, $\left.\mathrm{CH}_{2} \mathrm{CH}_{2}\right), 3.82\left(\mathrm{~d}, 1 \mathrm{H}, J=9.7 \mathrm{~Hz}, \mathrm{H}-2^{\prime}\right), 3.67\left(\mathrm{~s}, 3 \mathrm{H}, \mathrm{OCH}_{3}\right), 3.21$ (m, 1H, H-5'), 3.02 (m, 1H, H-3'); ESI-MS: $m / z[\mathrm{M}+\mathrm{H}]^{+}: 414.2$.

$N, N$-1,2-di-(1-O-(2-(acridine-9-yl)ethyl)- $\beta$-D-glucuronamide) ethane (3b)

This compound was prepared from $2 \mathbf{b}(0.24 \mathrm{~g}, 0.58 \mathrm{mmol})$ and ethylenediamine $(0.017 \mathrm{~g}, 0.29 \mathrm{mmol})$ using the same procedure as described for 3a. Purification of the residue resulted in $3 \mathbf{c}$ (40 $\mathrm{mg}, 16.7 \%$ yield) as a light yellow solid. mp $213-216{ }^{\circ} \mathrm{C} .{ }^{1} \mathrm{H}$ NMR (DMSO- $\left.d_{6}, 600 \mathrm{MHz}\right) \delta: 8.42$ (m, 2H, H-4, H-5), 8.12 (m, 2H, H-1, H-8), 8.03 (s, 1H, NH), 7.81 (t, 2H, J = 7.3, 7.8 Hz, H-3, H-6), 7.62 (t, 2H, $J=7.7,7.4 \mathrm{~Hz}, \mathrm{H}-2, \mathrm{H}-7), 5.10$ (m, 3H, 3OH), 4.35 (d, 1H, $J=7.8 \mathrm{~Hz}, \mathrm{H}-1$ '), 3.94 (m, 4H, $\mathrm{CH}_{2} \mathrm{CH}_{2}$ ), $3.57\left(\mathrm{~d}, 1 \mathrm{H}, J=9.6 \mathrm{~Hz}, \mathrm{H}-2^{\prime}\right), 3.17\left(\mathrm{~m}, 1 \mathrm{H}, \mathrm{H}-5\right.$ ') $3.15\left(\mathrm{~b}, 2 \mathrm{H}, \mathrm{CH}_{2} \mathrm{~N}\right), 3.04\left(\mathrm{~m}, 1 \mathrm{H}, \mathrm{H}-3^{\prime}\right) .{ }^{13} \mathrm{C}$ NMR (DMSO- $\left.d_{6}, 150 \mathrm{MHz}\right) \delta: 168.9,148.0,142.50,123.0,129.7,125.9,124.9,124.9,103.4,76.1,75.7$, 73.1, 71.4, 69.0, 38.2, 28.0; ESI-MS: $m / z$ [M+H] $]^{+}$: 823.6; HRMS (ESI): calcd. for $\mathrm{C}_{44} \mathrm{H}_{46} \mathrm{~N}_{4} \mathrm{O}_{12} \mathrm{Na}^{+}$ 845.3010 , found 845.3045 .

6-Cloro-9-(methyl 2,3,4-tri-O-acetyl-1-deoxy- $\beta$-D-glucuronosyluronate)purine (1c)

Glucuronosyl bromide $3(3.0 \mathrm{~g}, 7.5 \mathrm{mmol})$ was added to an azeotropically dried mixture of Cloromercuri-6-chloropurine (3.5 g, $9 \mathrm{mmol})$, Celite $(3 \mathrm{~g})$ and cadmium ( $3.3 \mathrm{~g}, 18.75 \mathrm{mmol})$ in toluene $(150 \mathrm{~mL})$, followed by $3 \mathrm{~h}$ of heating under reflux and then filtrated through Celite. The hot $\mathrm{CH}_{2} \mathrm{Cl}_{2}$-soluble material was collected from the filter cake and from the residue obtained on evaporation of the filtrate. The extract was washed twice with aqueous potassium iodide, twice with water and dried over $\mathrm{MgSO}_{4}$ and concentrated. The residue was purified on silica gel column chromatography (petroleum ether: EtOAc $=3: 2)$ to give $1.25 \mathrm{~g}(35 \%$ yield $)$ of $1 \mathrm{c}$ as a white solid (mp 223-224 $\left.{ }^{\circ} \mathrm{C}\right) .{ }^{1} \mathrm{H}$ NMR (DMSO- $\left.d_{6}, 600 \mathrm{MHz}\right) \delta: 9.12$ (s, $\left.1 \mathrm{H}, \mathrm{H}-2\right), 8.88(\mathrm{~s}, 1 \mathrm{H}, \mathrm{H}-8), 6.45$ (d, 1H, $\left.J=9.2 \mathrm{~Hz}, \mathrm{H}-1^{\prime}\right), 5.98$ (dd, 1H, $J=9.2,9.6 \mathrm{~Hz}, \mathrm{H}-3$ '), 5.75 (dd, 1H, $\left.J=9.6,9.2 \mathrm{~Hz}, \mathrm{H}-2^{\prime}\right), 5.32$ $\left(\mathrm{dd}, 1 \mathrm{H}, J=9.6,10.1 \mathrm{~Hz}, \mathrm{H}-4^{\prime}\right), 4.92\left(\mathrm{~d}, 1 \mathrm{H}, J=10.1 \mathrm{~Hz}, \mathrm{H}-5{ }^{\prime}\right), 3.62$ (s, 3H, $\left.\mathrm{OCH}_{3}\right), 1.71-2.04$ 
(3s, each3H, Ac-H); ${ }^{13} \mathrm{C}$ NMR (DMSO-d, $150 \mathrm{MHz}$ ); $\delta: 169.5,169.4,168.9,152.4,151.7,149.6$, $145.8,130.7,79.3,72.8,71.2,69.8,68.4,52.6,20.3,19.9$; ESI-MS: $m / z[\mathrm{M}+\mathrm{H}]^{+}: 471.0$.

6-methoxyl-9-(methyl $\beta$-D-glucuronosyluronate)purine (2c)

A solution of $1 \mathrm{c}(1.2 \mathrm{~g}, 2.55 \mathrm{mmol})$ in methanol $(35 \mathrm{~mL})$ was treated with sodium methoxide $(0.4 \mathrm{~mol} / \mathrm{L}, 8.75 \mathrm{~mL}, 3.5 \mathrm{mmol})$ for $8 \mathrm{~h}$ at room temperature. The reaction mixture was acidified to pH 6 by addition of Amberlite IR-120 $\left(\mathrm{H}^{+}\right)$. The resin was removed by filtration, and the filtrate was concentrated, then purified on silica gel column chromatography eluted with EtOAc to give $0.66 \mathrm{~g}$ (76.7\% yield) of $2 \mathrm{c}$ as a white solid. mp 245-247 ${ }^{\circ} \mathrm{C} .{ }^{1} \mathrm{H}$ NMR (DMSO- $\left.d_{6}, 600 \mathrm{MHz}\right) \delta: 8.61(\mathrm{~s}, 1 \mathrm{H}$, H-2), 8.57 (s, 1H, H-8), 5.66 (d, 1H, $J=9.2 \mathrm{~Hz}, \mathrm{H}-1$ '), $5.56(\mathrm{~d}, 1 \mathrm{H}, J=6.0 \mathrm{~Hz}, \mathrm{OH}), 5.53(\mathrm{~d}, 2 \mathrm{H}$, $J=5.5 \mathrm{~Hz}, 2 \mathrm{OH}), 4.19$ (m, 1H, H-2'), 4.12 (d, 1H, $\left.J=9.6 \mathrm{~Hz}, \mathrm{H}-5^{\prime}\right), 4.10$ (s, 1H, $\left.\mathrm{OCH}_{3}\right), 3.64(\mathrm{~s}, 1 \mathrm{H}$, $\mathrm{COOCH}_{3}$ ), 3.57 (m, 1H, H-4'), 3.48 (m, 1H, H-3'); ${ }^{13} \mathrm{C}$ NMR (DMSO-d, $150 \mathrm{MHz}$ ) $\delta: 168.7,160.34$, $152.2,151.9,142.7,120.7,83.1,77.6,76.2,71.2,70.5,54.0,52.0$; ESI-MS: $m / z[\mathrm{M}+\mathrm{H}]^{+}: 341.0$.

$N, N$-1,2-di-(1-deoxy-1-(6-chloropurine-9-yl)- $\beta$-D-glucuronamide)ethane (3c)

This compound was prepared from $2 \mathrm{c}(0.63 \mathrm{~g}, 1.85 \mathrm{mmol})$ and ethylenediamine $(0.06 \mathrm{~g}$, $0.97 \mathrm{mmol}$ ) using the same procedure as described for 3a. Purification of the residue with silica gel column chromatography (EtOAc: $\mathrm{MeOH}=3: 1)$ resulted in 3c (120 mg, 19.3\% yield) as a white solid. $\mathrm{mp}>250{ }^{\circ} \mathrm{C}$. ${ }^{1} \mathrm{H}$ NMR (DMSO- $\left.d_{6}, 600 \mathrm{MHz}\right) \delta: 8.62$ (s, $\left.1 \mathrm{H}, \mathrm{H}-2\right), 8.56$ (s, $\left.1 \mathrm{H}, \mathrm{H}-8\right), 8.16$ (br s, $1 \mathrm{H}$, $\mathrm{NH}), 5.56\left(\mathrm{~d}, 1 \mathrm{H}, J=9.2 \mathrm{~Hz}, \mathrm{H}-1^{\prime}\right), 5.46(\mathrm{~d}, 1 \mathrm{H}, J=5.9 \mathrm{~Hz}, \mathrm{OH}), 5.45(\mathrm{~d}, 1 \mathrm{H}, J=4.6 \mathrm{~Hz}, \mathrm{OH}), 5.37$ (d, $1 \mathrm{H}, J=5.0 \mathrm{~Hz}, \mathrm{OH}), 4.11\left(\mathrm{~s}, 3 \mathrm{H}, \mathrm{OCH}_{3}\right), 4.06$ (m, 1H, H-2'), 3.85 (d, 1H, $\left.J=9.6 \mathrm{~Hz}, \mathrm{H}-5^{\prime}\right), 3.57$ (m, 1H, H-4'), 3.43 (m, 1H, H-3'), 3.08 (br s, 2H, $\mathrm{NCH}_{2}$ ); ${ }^{13} \mathrm{C}$ NMR (DMSO-d $\left.6,150 \mathrm{MHz}\right) \delta: 167.9$, $160.3,152.2,151.8,142.5,120.6,82.9,78.1,76.6,71.0,70.9,54.0,38.0$; ESI-MS: $m / z[\mathrm{M}+\mathrm{H}]^{+}: 676.3$; HRMS (ESI): calcd. for $\mathrm{C}_{26} \mathrm{H}_{33} \mathrm{~N}_{10} \mathrm{O}_{12}{ }^{+}$677.2279, found 677.2290 .

$N$-(methyl-2,3,4-tri- $O$-acetyl-1-deoxy- $\beta$-D-glucuronosyluronate)-2-(indol-3-yl) acetamide (1d)

Reaction of azide 4 with $\mathrm{Pd} / \mathrm{C}$ in dry THF at $-5{ }^{\circ} \mathrm{C}$ under $\mathrm{H}_{2}$ gave amine 5 and its $\alpha$-anomer in a 13:1 ratio after filtration and removal of solvent. The freshly prepared amine was added to a solution of 2-(indole-3-yl) acetic acid (1.1 g, $6 \mathrm{mmol})$ and EDCI (1.15 g, $6 \mathrm{mmol})$ in $50 \mathrm{~mL}$ THF containing $0.5 \mathrm{~mL}$ water. The reaction mixture was stirred for $24 \mathrm{~h}$ at room temperature. After being concentrated, the residue was dissolved in $50 \mathrm{~mL}$ EtOAc and washed three times with water. The organic phase was dried over $\mathrm{MgSO}_{4}$ and filtered, and the solvent was removed under reduced pressure to give a mixture of products that was purified by column chromatography (petroleum ether: EtOAc $=1: 1$ ) to give $0.87 \mathrm{~g}\left(29.6 \%\right.$ yield) of $\mathbf{1 d}$ as a white solid (mp 198-200 $\left.{ }^{\circ} \mathrm{C}\right) .{ }^{1} \mathrm{H}$ NMR (DMSO- $\left.d_{6}, 600 \mathrm{MHz}\right) \delta: 10.90$ (s, 1H, indol-NH), 8.84 (d, 1H, $J=9.7 \mathrm{~Hz}$, sugar-NH), 7.48 (d, 1H, J = 7.8 Hz, H-4), 7.33 (d, 1H, $J=7.7 \mathrm{~Hz}, \mathrm{H}-7), 7.15$ (d, 1H, $J=2.3 \mathrm{~Hz}, \mathrm{H}-2), 7.05$ (m, 1H, H-5), 6.94 (m, 1H, H-6), 5.47 (dd, 1H, $\left.J=9.2,9.6 \mathrm{~Hz}, \mathrm{H}-1^{\prime}\right), 5.41\left(\mathrm{dd}, 1 \mathrm{H}, J=9.6,9.7 \mathrm{~Hz}, \mathrm{H}-3^{\prime}\right), 4.90$ (m, 2H, H-4', H-5'), 4.56 (d, 1H, $\left.J=9.6 \mathrm{~Hz}, \mathrm{H}-2^{\prime}\right), 3.62\left(\mathrm{~s}, 3 \mathrm{H}, \mathrm{OCH}_{3}\right), 3.52\left(\mathrm{~d}, 2 \mathrm{H}\right.$, indol- $\left.\mathrm{CH}_{2}\right), 1.98$ (s, 3H, Ac-H), 1.93 (s, 3H, Ac-H), 1.67 (s, 3H, Ac-H); ESI-MS: $m / z[\mathrm{M}+\mathrm{H}]^{+}: 491.1$. 
$N$-(methyl $\beta$-D-glucuronosyluronate)-2-(indol-3-yl)acetamide (2d)

A solution of $1 \mathbf{d}(0.83 \mathrm{~g}, 1.7 \mathrm{mmol})$ in methanol $(25 \mathrm{~mL})$ was treated with methanolic $\mathrm{NaOMe}$ $(0.4 \mathrm{~mol} / \mathrm{L}, 0.8 \mathrm{~mL})$ for $8 \mathrm{~h}$ under ice bath. The reaction mixture was acidified to $\mathrm{pH} 6$ by addition of Amberlite IR-120 $\left(\mathrm{H}^{+}\right)$. The resin was removed by filtration, the filtrate was concentrated and a brown solid (2d, $0.6 \mathrm{~g}, 97.4 \%$ yield) was obtained (mp 186-188 $\left.{ }^{\circ} \mathrm{C}\right) .{ }^{1} \mathrm{H}$ NMR (DMSO- $\left.d_{6}, 600 \mathrm{MHz}\right) \delta: 10.86$ (s, 1H, indole-NH), $8.66(\mathrm{~d}, 1 \mathrm{H}, J=9.2 \mathrm{~Hz}$, sugar-NH), $7.55(\mathrm{~d}, 1 \mathrm{H}, J=7.8 \mathrm{~Hz}, \mathrm{H}-4), 7.32(\mathrm{~d}, 1 \mathrm{H}$, $J=8.3 \mathrm{~Hz}, \mathrm{H}-7), 7.19$ (d, 1H, $J=2.7 \mathrm{~Hz}, \mathrm{H}-2), 7.05$ (m, 1H, H-5), 6.95 (m, 1H, H-6), 5.30 (d, 1H, $J=5.9 \mathrm{~Hz}, \mathrm{OH}), 5.19(\mathrm{~d}, 1 \mathrm{H}, J=5.0 \mathrm{~Hz}, \mathrm{OH}), 5.06(\mathrm{~d}, 1 \mathrm{H}, J=5.5 \mathrm{~Hz}, \mathrm{OH}), 4.80(\mathrm{dd}, 1 \mathrm{H}, J=8.7,9.2 \mathrm{~Hz}$, H-1'), 3.71 (d, 1H, $\left.J=9.6 \mathrm{~Hz}, \mathrm{H}-5^{\prime}\right), 3.63$ (s, 3H, $\left.\mathrm{OCH}_{3}\right), 3.54$ (d, 2H, $J=4.1 \mathrm{~Hz}$, indole- $\left.\mathrm{CH}_{2}\right), 3.31$ (m, 1H, H-2'), 3.25 (m, 1H, H-4'), 3.18 (m, 1H, H-3'). ESI-MS: $m / z[\mathrm{M}+\mathrm{H}]^{+}: 365.1$.

$N, N$-1,2-di-(1-deoxy-1- $N$-(2-(indol-3-yl)acetamide)- $\beta$-D-glucuronamide)ethane (3d)

This compound was prepared from $2 \mathbf{d}(0.6 \mathrm{~g}, 1.7 \mathrm{mmol})$ and ethylenediamine $(0.05 \mathrm{~g}, 0.84 \mathrm{mmol})$ using the same procedure as described for 3a. The mixture was stirred under reflux for 1 week, the precipitate formed was filtered and washed with hot methanol $(10 \mathrm{~mL} \times 3)$, then dried under high vacuum, and 3d (80 mg, 13.4\% yield) as a brown solid was obtained. $\mathrm{mp}>250{ }^{\circ} \mathrm{C} .{ }^{1} \mathrm{H} \mathrm{NMR}$ (DMSO- $d_{6}$, $600 \mathrm{MHz}) \delta: 10.86(\mathrm{~s}, 1 \mathrm{H}$, indol-NH), $8.63(\mathrm{~d}, 1 \mathrm{H}, J=9.2 \mathrm{~Hz}$, sugar-NH), $8.08(\mathrm{~s}, 1 \mathrm{H}), 7.56(\mathrm{~d}, 1 \mathrm{H}$, $J=7.8 \mathrm{~Hz}, \mathrm{H}-4), 7.32$ (d, 1H, $J=7.8 \mathrm{~Hz}, \mathrm{H}-7), 7.19$ (s, 1H, H-2), 7.05 (dd, 1H, J=7.4, $7.3 \mathrm{~Hz}, \mathrm{H}-5$ ), $6.95(\mathrm{dd}, 1 \mathrm{H}, J=7.7,6.9 \mathrm{~Hz}, \mathrm{H}-6), 5.13(\mathrm{dd}, 2 \mathrm{H}, J=4.1,4.6 \mathrm{~Hz}, \mathrm{OH}), 5.00(\mathrm{~d}, 1 \mathrm{H}, J=5.5 \mathrm{~Hz}, \mathrm{OH})$, $4.76\left(\mathrm{dd}, 1 \mathrm{H}, J=9.2,8.7 \mathrm{~Hz}, \mathrm{H}-1^{\prime}\right), 3.54$ (s, 2H, indol- $\left.\mathrm{CH}_{2}\right), 3.51$ (d, 1H, J = 9.6 Hz, H-5'), 3.33 (m, 1H, H-2'), 3.18 (m, 2H, H-4', H-3'), 3.09 (b, 2H, NCH 2 ); ${ }^{13} \mathrm{C}$ NMR (DMSO-d 6 , $150 \mathrm{MHz}$ ) $\delta: 171.3,168.5$, 136.0, 127.3, 123.8, 120.9, 118.9, 118.2, 111.2, 108.4, 79.9, 77.5, 77.1, 72.1, 71.2, 38.1, 32.6; ESI-MS: $m / z[\mathrm{M}+\mathrm{H}]^{+}:$725.2. HRMS(ESI): calcd. for $\mathrm{C}_{34} \mathrm{H}_{41} \mathrm{~N}_{6} \mathrm{O}_{12}{ }^{+}, 725.2782$, found 725.2761.

\section{Conclusions}

DNA bis-intercalators has drawn considerable attention because of higher DNA-binding constants, slower dissociation rates and substantial sequence selectivity. We designed and synthesized a series of novel potential DNA bis-intercalators, in which two glucuronic acids were linked by ethylenediamine, and the glucuronic acid was coupled with various chromophores, including quinoline, acridine, indole and purine, at the $\mathrm{C}-1$ position. The preliminary binding properties of these compounds to calf thymus DNA (CT-DNA) have been investigated by UV-absorption and fluorescence spectroscopy. The results indicated that all the target compounds can interact with CT-DNA, and the acridine derivative, $\mathbf{3 b}$, showed the highest key selection vector (KSV) value, which suggested that compound $\mathbf{3 b}$ binds most strongly to CT-DNA and deserves further development.

\section{Acknowledgements}

This work was supported by Specialized Research Fund for the Doctoral Program of Higher Education (Grant No. 20110132110003) and the Program for Changjiang Scholars and Innovative Research Team in University (IRT0944). 


\section{Supporting Information Available}

${ }^{1} \mathrm{H}$ NMR and ${ }^{13} \mathrm{C}$ NMR spectra for new compounds are shown in supplementary material.

\section{Conflicts of Interest}

The authors declare no conflict of interest.

\section{References}

1. Hartley, J.A.; Hochhauser, D. Small molecule drugs-optimizing DNA damaging agent-based therapeutics. Curr. Opin. Pharmacol. 2012, 12, 398-402.

2. Srinivasan, A.; Gold, B. Small-molecule inhibitors of DNA damage-repair pathways: An approach to overcome tumor resistance to alkylating anticancer drugs. Future Med. Chem. 2012, 4, 1093-1111.

3. Li, V.S.; Choi, D.; Wang, Z.; Jimenez, L.S.; Tang, M.S.; Kohn, H. Role of the C-10 substituent in mitomycin C-1-DNA bonding. J. Am. Chem. Soc. 1996, 118, 2326-2331.

4. Zuber, G.; Quada, J.C.; Hecht, S.M. Sequence selective cleavage of a DNA octanucleotide by chlorinated bithiazoles and bleomycins. J. Am. Chem. Soc. 1998, 120, 9368-9369.

5. Hecht, S.M. Bleomycin: New perspectives on the mechanism of action. J. Nat. Prod. 2000, 63, $158-168$.

6. Dervan, P.B. Molecular recognition of DNA by small molecules. Bioorg. Med. Chem. 2001, 9, 2215-2235.

7. Neidle, S. DNA minor-groove recognition by small molecules. Nat. Prod. Rep. 2001, 18, 291-309.

8. Xi, H.; Davis, E.; Ranjan, N.; Xue, L.; Hyde-Volpe, D.; Arya, D.P. Thermodynamics of nucleic acid "shape readout" by an aminosugar. Biochemistry 2011, 50, 9088-9113.

9. Kumar, S.; Xue, L.; Arya, D.P. Neomycin-neomycin dimer: An all-carbohydrate scaffold with high affinity for AT-rich DNA duplexes. J. Am. Chem. Soc. 2011, 133, 7361-7375.

10. Hamilton, P.L.; Arya, D.P. Natural product DNA major groove binders. Nat. Prod. Rep. 2012, 29, 134-143.

11. Greguric, I.; Aldrich-Wright, J.R.; Collins, J.G. A1H NMR study of the binding of $\Delta$-[Ru(phen)2DPQ $]^{2+}$ to the hexanucleotide $\mathrm{d}(\mathrm{GTCGAC}) 2$. evidence for intercalation from the minor groove. J. Am. Chem. Soc. 1997, 119, 3621-3622.

12. Filichev, V.V.; Pedersen, E.B. DNA-Conjugated Organic Chromophores in DNA Stacking Interactions. Wiley Encycl. Chem. Biol. 2008, doi:10.1002/9780470048672.wecb654.

13. Brana, M.F.; Cacho, M.; Gradillas, A.; de Pascual-Teresa, B.; Ramos, A. Intercalators as anticancer drugs. Curr. Pharm. Des. 2001, 7, 1745-1780.

14. Ross, W.E.; Bradley, M.O. DNA double-strand breaks in mammalian-cells after exposure to intercalating agents. Biochim. Biophys. Acta 1981, 654, 129-134.

15. Tewey, K.M.; Rowe, T.C.; Yang, L.; Halligan, B.D.; Liu, L.F. Adriamycin-induced DNA damage mediated by mammalian DNA topoisomerase II. Science 1984, 226, 466-468. 
16. Chaires, J.B.; Leng, F.; Przewloka, T.; Fokt, I.; Ling, Y.H.; Perez-Soler, R.; Priebe, W. Structure-based design of a new bisintercalating anthracycline antibiotic. J. Med. Chem. 1997, 40, 261-266.

17. Kuruvilla, E.; Joseph, J.; Ramaiah, D. Novel bifunctional acridine-acridinium conjugates: Synthesis and study of their chromophore-selective electron-transfer and DNA-binding properties. J. Phys. Chem. B 2005, 109, 21997-22002.

18. Lorente, A.; Vazquez, Y.G.; Fernandez, M.J.; Ferrandez, A. Bisacridines with aromatic linking chains. Synthesis, DNA interaction, and antitumor activity. Bioorg. Med. Chem. 2004, 12, 4307-4312.

19. Xue, L.; Xi, H.; Kumar, S.; Gray, D.; Davis, E.; Hamilton, P.; Skriba, M.; Arya, D.P. Probing the recognition surface of a DNA triplex: Binding studies with intercalator-neomycin conjugates. Biochemistry 2010, 49, 5540-5552.

20. Willis, B.; Arya, D.P. Triple recognition of B-DNA by a neomycin-Hoechst 33258-pyrene conjugate. Biochemistry 2010, 49, 452-469.

21. Willis, B.; Arya, D.P. Triple recognition of B-DNA. Bioorg. Med. Chem. Lett. 2009, 19, 4974-4979.

22. Shaw, N.N.; Xi, H.; Arya, D.P. Molecular recognition of a DNA:RNA hybrid: Sub-nanomolar binding by a neomycin-methidium conjugate. Bioorg. Med. Chem. Lett. 2008, 18, 4142-4145.

23. Arya, D.P.; Xue, L.; Tennant, P. Combining the best in triplex recognition: Synthesis and nucleic acid binding of a BQQ-neomycin conjugate. J. Am. Chem. Soc. 2003, 125, 8070-8071.

24. Xue, L.; Charles, I.; Arya, D.P. Pyrene-neomycin conjugate: Dual recognition of a DNA triple helix. Chem. Commun. 2002, 70-71.

25. Wunberg, T.; Kallus, C.; Opatz, T.; Henke, S.; Schmidt, W.; Kunz, H. Carbohydrates as multifunctional chiral scaffolds in combinatorial synthesis. Angew. Chem. Int. Edit. 1998, 37, 2503-2505.

26. Velasco-Torrijos, T.; Murphy, P.V. Synthesis and conformational analysis of novel water soluble macrocycles incorporating carbohydrates, including a $\beta$-cyclodextrin mimic. Tetrahedron 2005 , 16, 261-272.

27. Liu, C.H.; Liu, H.; Han, X.Y.; Wu, B.; Zhong, B.H.; Gong, Z.H. Synthesis and characterization of thienorphine and its glucuronide conjugate. Synthetic. Commun. 2005, 35, 701-710.

28. Chiba, T.; Sinay, P. Application of a radical reaction to the synthesis of L-iduronic acid-derivatives from D-glucuronic acid analogs. Carbohyd. Res. 1986, 151, 379-389.

29. Florio, P.; Thomson, R.J.; von Itzstein, M. Rapid access to uronic acid-based mimetics of Kdn2en from D-glucurono-6,3-lactone. Carbohydr. Res. 2000, 328, 445-448.

30. Pitt, N.; Duane, R.M.; O’Brien, A.; Bradley, H.; Wilson, S.J.; O’Boyle, K.M.; Murphy, P.V. Synthesis of a glucuronic acid and glucose conjugate library and evaluation of effects on endothelial cell growth. Carbohydr. Res. 2004, 339, 1873-1887.

31. Wolfrom, M.L.; McWain, P. Nucleosides of D-glucuronic acid and of D-glucofuranose and D-galactofuranose. J. Org. Chem. 1965, 30, 1099-1101.

32. Liu, Z.Q.; Li, Y.T.; Wu, Z.Y.; Song, Y.L. A two-dimensional copper(II) polymer with bridging $\mu$-trans-oxamidate and $\mu 2$-picrate ligands: Synthesis, crystal structure and DNA binding studies. Inorg. Chim. Acta 2008, 361, 226-232. 
33. Zhou, J.H.; Xia, S.Q.; Chen, J.R.; Wang, X.S.; Zhang, B.W.; Zhang, H.J.; Zou, P.; Ai, X.C.; Zhang, J.P. Surface binding and improved photodamage of the lanthanum ion complex of hypocrellin A to calf thymus DNA. J. Photoch. Photobio. A 2004, 165, 143-147.

34. Zhang, Q.Q.; Zhang, F.; Wang, W.G.; Wang, X.L. Synthesis, crystal structure and DNA binding studies of a binuclear copper(II) complex with phenanthroline. J. Inorg. Biochem. 2006, 100, 1344-1352.

35. Song, Y.F.; Yang, P. Mononuclear tetrapyrido[3,2-a:2',3'-c:3",2"-h:2'",3"'-j]phenazine (tpphz) cobalt complex. Polyhedron 2001, 20, 501-506.

36. Han, M.J.; Duan, Z.M.; Hao, Q.; Zheng, S.Z.; Wang, K.Z. Molecular light switches for calf thymus DNA based on three Ru(II) bipyridyl complexes with variations of heteroatoms. J. Phys. Chem. C 2007, 111, 16577-16585.

37. Patel, D.J. Nuclear magnetic-resonance studies of drug-nucleic acid interactions at the synthetic DNA level in solution. Accounts Chem. Res. 1979, 12, 118-125.

38. Kumar, C.V.; Barton, J.K.; Turro, N.J. Photophysics of ruthenium complexes bound to double helical DNA. J. Am. Chem. Soc. 1985, 107, 5518-5523.

39. Chen, Y.D.; Cai, M.Y.; Zhang, Y.; Zheng, W.L.; Ma, W.L. Study on the mechanism of chitosan complex formation with PEGF-PC ${ }_{3}$ DNA (in Chinese). Pharm. Biotechnol. 2005, 12, 291-293

40. Stern, O.; Volmer, M. Uber die abklingungszeit der fluoreszenz. Phys. Z. 1919, 20, 183-188.

41. Marmur, J. A procedure for the isolation of deoxyribonucleic acid from micro-organisms. J. Mol. Biol. 1961, 3, 208-218.

42. Reichmann, M.E.; Rice, S.A.; Thomas, C.A.; Doty, P. A further examination of the molecular weight and size of desoxypentose nucleic acid. J. Am. Chem. Soc. 1954, 76, 3047-3053.

(C) 2013 by the authors; licensee MDPI, Basel, Switzerland. This article is an open access article distributed under the terms and conditions of the Creative Commons Attribution license (http://creativecommons.org/licenses/by/3.0/). 